\title{
Emergence of Neo-imperialism and The Perils Confronting Natural Resources of Developing Nations
}

Krishna Roka*

\section{Introduction}

Hong Kong and Macao may have been last of the few territories of the old imperialistic regimes, i.e. the Europeans. With the end of World War II, the conquerors began to retreat, as a result many nations became freed, and a new world order governed by trade emerged. When one of the last nations was getting freedom from the imperialistic force a new form of neo-imperialism force was burgeoning, like "old bottle new wine". The name of the new colonial force is "globalization", and the riders of this force are the Europeans, Americans and few Asian nations. With its inception during the 1980s, globalization has taken in many forms, the latest being the World Trade Organization (WTO) - the central commander of globalization. Trade and economy are its weapons. Trade and trading among nations is the leading factor in establishing friendly relationships or confrontations sometimes resulting in the conquering of defeated nations. The old imperialistic forces prevailed, expanded and captured other nations utilizing their trade links. Similarly, the new force too adapted the old theory; in the name of trade and economics these nations have established themselves as the rulers of the new world. The old forces relied on direct conflicts to defeat and capture but the new forces use other means like trade sanctions, blockage of funds, and other aids, in the name of development and democracy. Using these facts they are compelling the weaker nations to comply to their demands like- exporting oils, minerals, raw natural products, timbers, etc. and importing electronic goods, tobacco products, clothes, and finished products.

The two important areas adversely affected by both the old and new imperialism forces are natural resources and culture. Of these two areas this paper focuses on natural resources. History is abundant with the loss of natural wealth and cultural value in the conquered nations. Tracts and tracts of forests disappeared across the globe, millions of animals were killed in land and sea, hundreds species have become extinct, many pristine areas were converted to plantations and agricultural lands; and amassing of the valuable and income by the conquerors, are just a few of the many. Culturally, hundreds of indigenous culture and people have either disappeared or have been forced to change to the new culture of the Europeans. The best example for both can be found in South America, where the nations lost both their natural resources and cultural values with the presence of Europeans; collapse of the Inca and Mayan empire is the best example of the impact of the conquistadors.

Mountainous regions of the world, the cradle or birthplace of most of the present crops, medicine and other products have been the focal center throughout the history. As stated by IUCN (1999), exploitation of Himalayan genetic resources has never ensured benefit sharing to Himalayan people; the red jungle fowl of this region is the progenitor of the world's chicken. How much of the world's chicken markets plough their profits back into conserving the red jungle fowl? None. Similarly the reserpine has something like US USD 40 million market annually in USA, but Nepal, India and other countries remain empty handed in spite of the fact that Rauwolfia, the sole source of reserpine, belongs to this regions and the ethno-pharmacological knowledge that led to the discovery of reserpine belonged to the people of this region.

\footnotetext{
* Teaching Assistant Socialogy, Mahedra M.C. Baglung.
} 
The new colonial empire "globalization" and its many agents have proven fruitful to its inceptors and deadly to the developing nations. The failure of the Cancun talks of the WTO on September 2003, the resentment of the developing nations and the hegemonic attitudes of the northern bloc, proves that globalization indeed is the new colonial power. In the name of economic reforms, human rights and freedom of expressions, forces far away at Washington, Geneva and London, are influencing the activities of developing nations, the major motivation being protecting their self-interests at the cost of other weaker nation's resources. Most of the top 15 third world debtors have tripled the rate of exploitation of their forests since the late 1970s. This is related to the survival imperative of poor, landless people who depend on forest resources and the pressing need of nations to gain foreign exchange for debt servicing (Bello 1994). The major agents of globalization are trade, Trade Related Intellectual Property Rights (TRIPS), Multinational Companies (MNCs), tourism, and agriculture sectors. Globalization presents a new opportunities for developing countries by creating new opportunities in various sectors -economy, employment, innovations, trade etc., but also cloaks new risks for them. WTO sidelines environmental rules, health safeguards and labor standards to provide Transnational Companies (TNCs) with a cheap supply of labor and natural resources (Thacker 2003).

Trade is not a new word; for millennia it has existed and helped to flourish products and culture across the world. Globalization is heavily depended upon trade to achieve its mission. For this the gist policy has been market liberalization or free trade, and promoted as a cure for poverty and enhancement of developmental and economical activities. But against their projection these policies are undermining the importance of natural resources in the lives of the rural poor, for they view these resources as a bountiful source of income, proven by history. For, the trend is the loss of forests, coral reefs, land degradation, extinction of wildlife, etc., clearly indicates that these policies are having adverse effects on the resources of the developing countries. One apparent index of globalization is the brisk and growing trade in foodstuffs supplying affluent populations with exotic high value and all seasonal foods via corporate global sourcing arrangements. However, only about $20 \%$ of the world's 6 billion people participate in the cash on consumer credit economy (McCalla 1999). Out of this $20 \%$ too, it can be easily put that a meager number belong to the developing states.

Of all the natural resources, forestry is the most exploited and most valuable. The economic value of forest is inestimable. Among the non-food plants traded internationally on commercial levels are at least 200 species of timber trees, 42 species of oil plants, 66 species yielding latexes or gums, 13 species used as dyes and colorants, and hundreds as ornamental or horticultural qualities (Abramovitz 1998). Trade in forest products both legal and illegal is a strong economic force. Many nations view their forest as the last reserve to gain economic returns at times of distress. The volume of transactions on world finance is estimated in the range of USD1500 billion a day (Hariiot 2003). Tree harvesting has deleterious impact on forest ecosystem from the initial phase of the operation building roads to fragmentation, tree felling, transportation to transforming natural forest into monoculture plantations.

With growing level of interest in the trade of coral products, concerns have arisen in the face of exploitation. During 1985-1997 international coral trade was approximately 2 million coral pieces per year with the USA accounting $56 \%$ by weight of imports in global trade. The trade value was USD 5 million in 1997 to exporting nations and USD 50 million in retail sales (Harriot 2003), the bulk of the earnings landing in the hands of the outsiders from the source.

As stated by Junior and Welford (1997) trade and globalization have expanded the opportunities for the rich to pass on their environmental burdens to the poor by exporting both waste and pollution. New form of neo-colonial hegemony! As investors from the rich nations search the 
globe for the highest return, they are often drawn to places endowed with bountiful natural resources, as a result many people and communities are affected as the environment that sustain them is damaged or destroyed. With regional treaties like NAFTA and others, the developed countries are cajoling these nations in accepting the terms of exploitation. Mexico by signing the NAFTA treaty with USA and its implementation by 2008, as a result corn imports will rise by $200 \%$ and over two third of Mexican corn production will not survive the competition (Watkins 1996). Who is benefited?

International wildlife trade is another major commercial activity. It is estimated to be a worth a minimum of 10 billion dollars annually and it involves millions of animals every year. The USA is the world's largest consumer of wildlife products (WWF-US 2000). This trade in wild animals threatens species and deprives poor communities of food. The developed nations, follow the selfprotectionist and other's exploitation policy, their wildlife are protected and conserved squandering species in the Asia and Africa. The old colonial power, only after its resources were depleted searched for source to meet their demands, but the new regime is spreading its influence in other regions while saving their own resources. Also these nations have turned the world into a type of dependent states, and forced to export their agro-products while domestic populations die of hunger. Nowadays, South American, African and Asian nations are the fertile ground for western nations in terms of producing agro-products for them and dumping or selling their waste and finished products.

\section{Agriculture}

The area most affected with the expansions of old and new imperialistic forces is the agriculture sector. In the old system individuals appropriated rich lands for their use, but in the new system corporate are gaining access and amassing lands. These few corporate now control nearly $60 \%$ of the agro-production and trade in the world, the poor farmer and local entrepreneurs standing no chances against these giants. These Multi National Companies (MNCs) force local population to use their hybrid species, through institutional or governmental pressure. The developing nations get entrapped lured by the short term benefits from these hybrid species; initially they are assisted but later as the nations become dependent, they withdraw, with no alternative they must buy their seeds and other products. The use of hybrid seeds requires high use of pesticides and fertilizers, deleterious to the environment resulting in soil degradation and pollution, but beneficial to MNCs producing these products. Many local breeds of the crops have been lost in many nations by the use of hybrid seeds. The traditional seeds are now with the MNCs and the farmers have no access to them, and so manipulated unabling to reuse them. So they must buy them. Recent research discloses a total of 132 genetic patents on crops that evolved in the south but are now grown worldwide: 68 for maize genes, 17 for potato, 25 for soybean and 22 for wheat (Action Aid 2000). Pesticides like DDT produced but banned in the west are easily available and heavily used in developing nations highly promoted by the producers, turning these nations into dumping ground of harmful products and earning in return. Agriculture constitutes $65 \%$ of the global economy and corporate centralization is unsurprising: The top ten agrochemical companies control $81 \%$ of the USD29 billion global agrochemical market. Ten life science companies control $37 \%$ of the USD15 billion per year global seed market. The world's ten major pharmaceutical companies control 47\% of the USD197 billion pharmaceutical trade (Rifken 1998). In 1990, the OECD countries controlled $90 \%$ of the global seed market. From 1970-1996 the OECD share in volume of world cereal exports rose from $73 \%$ to $82 \%$; the US remained the world's major exporter of commercial crops such as maize, soybean, and wheat; and the share of Africa, Latin America and Asia in world cereal imports increased to nearly 60\% (Pistorious and van Wijk 1999). 
With the development of newer techniques in developing and raising high yield species, the western states need viable market for their products. Using their economic muscle power, they are exporting these products to southern states at prices largely below the local products. In 1999 most of the 34 million hectares (ha) of GM crops were grown in north, by 2002 it is estimated that 550 million ha out of a world total of 900 million ha will be grown in the south (Action Aid 2000). As a result local farmers are more marginalized and local production coming to a halt and creating an externally dependent states. These crops are feared to displace or change the pattern of local ecosystems, creating havoc in the natural ecosystems. In the name of 'aid package' US is distributing food of GM origin, imposing risk to the local crops. The long-term impact of GM food cannot be ignored in countries where agriculture is still the lifeblood of local economies. The fear of GM species interacting with local species and giving rise to new breed of species always exists with their usage. So, we will be losing our market share and all local species, further degrading our ecosystem and making us vulnerable to the vicissitudes of trade, climate and economy. As of late September 2003, 653 scientists of 74 countries signed a letter calling the ban of GM foods. The letter expresses "extreme concern" about the hazards of GMOs to biodiversity, food safety, and human and animal health (Anonymous 2003).

\section{Tourism}

Tourism has emerged as a major source of revenue for countries specifically in the third world. Its growth has been nothing short of phenomenal. In the 1950s, 25 million people traveled and it foresees by the year 2010 one billion tourists would have traveled abroad (Matsny 2001). This shows the importance of tourism in the economy of the developing countries. Against their projection the revenue thus earned is not capitalized in the local economy, but funneled to distant areas in the north, also the movement is controlled by the corporate in these nations. The World Tourism Organization (WTO) and WTO, and their various institutions in the new form of imperialistic policies are directing many weak nations to act according to their will. In the name of liberalizing world economy, both WTOs has come forward with major three agreements, the General Agreement on Trade in Services (GATS), Trade Related Investment Measures (TRIMs), and Multilateral Agreement on Invests (MAI).

GATS signed in 1994, "sets up a legal and operational framework for the gradual elimination of barriers of international trade in services". In short, GATS makes it easier for big tourist and travel TNCs to invest in the local tourism industries of third world countries. Among others, it removes restrictions on foreign corporations, enabling them to use trademarks, create and operate branch offices abroad and most importantly, to repatriate their earnings to their mother companies abroad, while TRIMs removes the requirements for foreign companies to utilize local input and MAI secures unfettered rights for TNCs to invest in all sectors of host country and obtain same treatment as the host investors.

The WTO estimates that nearly $50 \%$ of tourism income leaks out of the developing nations and in some economies $75 \%$. Foreign-based operators dominate tourism sector in many countries, including Kenya, Tanzania and Zimbabwe. It is found that expatriates in many nations hold higher managerial positions; in Least Developed Countries (LDCs) 23\% of wage bill was earned by foreigners accounting to only $7 \%$ of the positions. In Belize, $90 \%$ of country's coastal developments are in foreign hands. The international hotels and other tourism establishments are denying access to locals in the adjacent areas, consequently controlling the local resources vital for local livelihood. For example, although Mexico's constitution guarantees public access to all beaches, the large hotels are increasingly denying such access, especially to people who don't appear to be white or tourists (Stevenson 1998). With the control of large areas in the hands of the entrepreneurs, exploration and research work too are affected. 
Heavy dependence on tourism sectors pressurizes host nations in meeting the tourist demands at environmental costs. New hotels, roads, resorts, golf courses, routes, etc. are created, transforming pristine and serene natural setting into hub of tourism activities resulting in forest loss, land fragmentation, species loss, and the many others. Adding to the constraints these industries are controlled by foreign nationals consuming massive resources leaving the locals to the perils of scarcity. Thus, taking advantage of local situation foreign based business are expanding and controlling local economies, presenting themselves as the new rulers of modern era.

\section{TNCs/ MNCs:}

Transnational Corporations or Multinational Companies (MNCs) are the missionary of globalization and the major weapon of neo-imperialistic states in expanding their influence to wider areas and dominating local economies and power with their economic robust. With a few exceptions these TNCs have proven as the agents of environmental degradation and destroying local systems. For TNCs dominate $80 \%$ of land worldwide cultivated for export crops; 20 firms account for $90 \%$ of pesticide sales, manufacture toxic chemicals like PCBs, DDT and dioxins and dominate the trade in natural resources $(T W N$ 1992). The failure of international agency to monitor and regulate TNCs, and the moves instead to widen their rights and access, have led to spectacular rise in their power and authority (TWN 1992), enabling them for wider outreach and dominating the developing nations. The fact is TNCs account for the largest part of the global economic activity and are the main entities responsible for the global environment crisis.

In recent years TNCs have concentrated on collecting seeds of various crops across the world intended to control the global market and production. As a result there is a rice bank in Philippines and wheat banks in New Mexico and Colorado, housing two million kinds of rice and wheat seeds. For example the American company Escogenetics has patented all coffee seeds genetically produced (Khadka 2000). Such accruing means weaker nations losing their rights of the crops and, in turn, spend their income in gaining access to the expensive seed source.

Just when the world needs national and international policies to reverse deforestation, leading industrialized nations are negotiating the MAI, which is designed to remove restrictions on the largest corporate investors. This agreement would give timber barons and mining companies greater access to some of the planet's last pristine forests. Governments must treat foreign investors "no less favorably" than domestic companies in the "acquisition, establishment and operation" of an investment. This means that if a country or state allows local companies to log or mine, it has to let multinational timber and mining companies do the same.

Governments that sign the MAI would lose their sovereign right to ensure that any economic activity in forests produces the maximum benefits for local residents, who have the most to lose from deforestation. When foreign companies do invest on private or public lands, the MAI will block governments from imposing certain conditions on foreign investors.

The MAI would also prevent governments from screening out companies with poor environmental records. Some international timber companies have particularly negative records of practicing "cut and run" in logging and engaging in illegal timber trade. Governments should be able to screen proposed foreign investment in forestry projects to keep these bad actors out of their countries. The MAI would bar any special scrutiny of foreign investors. A foreign investor could argue that a stringent ban on clear cutting or other land use restriction has the "effect of an expropriation", which requires compensation under the MAI's rules. (Valliantos and Durbin 1998). 
The agreement on Trade Related Intellectual Property Rights (TRIPS) established standards for the protection of intellectual property rights - including patents, copyrights, trademarks, industrial designs, geographic indication, layout designs (topographies) of integrated circuits, and trade sectors (Guru-Gharana 2001). Although initially it was conceptualized for industrial products, the controversy arose after patenting biological resources. The TRIPS contains a controversial provision that allows biological products to be patented also. This came after a ruling by the American Supreme Court on the Diamond vs Chakravarty case in 1980s. The ruling said that patents could be applied to living matter that had been produced through genetic engineering (Plahe et al. 2003). The irony is that TRIPS grew out of an attempt to stem intellectual property pirating of western products (watches, CDs etc.) in the south, and TRIPS appears now to sanction a reverse biological form of piracy on a disproportionate scale threatening livelihood, rather than commodity rights (Greenfield 1999).

Evidences are appearing that TRIPS has been building roads for the northern TNCs in accruing patent rights of local resources, with or without their consensus and finally controlling the sector. Under the WTO formulated in 1995, all WTO member states (and any new members) are required to grant at least twenty-year patent protection (called TRIPS) in all fields. TRIPS forces countries to relinquish their rights to produce or import low cost generic copies of patented goods. Violation of TRIPS triggers a complex and costly dispute, terminating with trade sanctions.

Cases of loss of patent rights of LDCs to MNCs are increasing at an alarming rate in recent years, and as Levinson (2002) states, TRIPS have moved beyond the proper function of patents, providing reasonable regards to investors in creating long-term monopolies in developing countries. The significance of the TRIPS protocol is that intellectual property rights on gene patenting tend to privilege governments and corporations as legal entities, and disempower communities and farmers whose rights over traditional knowledge go unrecognized. A case in point is the 1998 patenting of Indian basmati rice by the Texas based company Rice Tec Inc., which sells 'Texmati' rice as authentic basmati. A logical next step is to demand financial compensation from the hundreds of thousands of Indian small farmers who cultivate basmati rice, and monopolize the control and reproduction of seeds, using biotechnology (Greenfield 1999). Even though, the UN Convention on Biological Diversity, ratified by 183 countries and in force since 1993, recognizes the sovereignty of states and communities over their genetic resources.

With all these provisions, TNCs which control two third of the world trade in goods and services use their capital to submerge the competitors operating on a local or national level. This process has been helped by the pressure of international institutions like the International Monetary Fund (IMF), World Bank, etc. to open the national economies to foreign investors. As a consequence, MNCs have become such an economic power that can now impose their own economic trends, and influence, as well as protect their own trade market on a local, regional and continental scales. Should the MNCs succeed in acquiring the patent rights over biodiversity, then it will affect not only farmers, scientists, producers and consumers, but will also seriously cause a setback to research and study.

Facilitated by TRIPS and other agreements biopiracy is becoming much debated subject among the developed and developing nations. Biopiracy is the theft of biological matter, such as plants, seeds and genes. In the absence of laws regulating access to these resources, pharmaceutical, agrochemical and seed multinationals - companies dealing in seeds, exploit developing nations' biological wealth and obtain intellectual ownership rights to the resources and knowledge of communities. The thousands of patents cases in African plant have been filed, for example: brazzeine, a protein 500 times sweeter than sugar from a plant in Gabon; teff, the grain used in 
Ethiopia's flat "injera" bread; and many others. As stated before, MNCs make huge profits from these biodiversity but they do not share the profits to the communities that discovered (non-Wood News 2003). The situation is no less better in south America or in Asia where indigenous communities are losing their knowledge and resources to MNCs.

\section{Conclusions}

The time has come for the developing nations to reconcile their views regarding globalization. Globalization is not a magic wand to have magical effect of improving the situation with a single sweep. The various agents and their repercussions clearly show how these agents have forced us to cater to their needs. The best principle to protect ourselves is "be wary". Here is one example of an ad hoc implementation of government policies, lacking foresightedness and vision. Nepal, a nation plagued by poverty and violence, as a result of the insurgency the presence of government is absence in rural areas. As a result the government initiated providing services at the local level by organizing camps. Of the many services the officials are distributing "high breed seeds" to the local farmers. Do these officials ever envisage the long lasting impact of this act? The poor farmers are being made dependent on these seeds and losing their local stock of seeds. This had been the case in many regions and the organizations most benefited by such activities are the multinational seed companies. Is it wise for the government, making its people dependent on external sources? The many examples as cited above clearly forecast the outcome of such an act.

It can be concluded that these neo-imperialistic approaches have just a single motif - conquer and rule, similar to the old colonial state. In the past land acquisition and labor control was the method, nowadays it is economy and development. In the name of economical upliftment, their hegemony over developing nation has proven fatal for the local economy and environment. Constraintly their interests and corporations are benefiting. As long as their needs are met, these powerful states are not going to reconsolidate their position. Even though, many of the environmental problems like global warming, deforestation, species extinction, etc. are global in their effect; most have their root in these nations. Global warming, the most concerned in the $21^{\text {st }}$ century was born out of the urbanization, industrialization and life style pattern of the western states. Consumerism level high above the average means more production, more land transformation and more species lost. Global tourism is one aspect of facilitating the expansion of northern interest and making the host nations cash dependent on this sector.

Finally, just like the Homo sapiens displaced the Neanderthal, the west is trying to spread its influence across the globe in establishment of corporate dominated world. In the past they were successful, resulting in the division of the world into developed and underdeveloped. Now, they may seem or feel to be successful in controlling the world resources from their bases in America and Europe. But if the developing nations realize this threat and act accordingly, the linear projection of the west may go wrong. Or we can together work towards sustaining our resources, establishing an egalitarian society across the world and strive for frugal usage of the existing resources.

\section{Reference:}

Abromovitz, J.N. 1998. Taking A Stand: Cultivating A New Relationship With The World's Forests. World Watch Paper 140, World Watch Institute. Washington D.C.

ActionAid 2000. Crops and robbers. Biopiracy and the patenting of staple food crops. ActionAid.

Anonymous 1997. TNCs And Globalisation: Primary Sources Of Worsening Ecological Crisis, TWR No.81/82. www.twnside.org.sg/index.html

Anonymous 2003. Environmental Intelligence, World Watch Vol.16, No. 6. 
Bello, W. 2000. Does world trade need World Trade Organization? Businessworld, January 11.

Crop Development. Oxon: CABI Publishing.

Food Summit," The Ecologist 26, 6: 244-255.

Guru-gharana, K.K. 2001. The WTO And The Least Developed Countries, in WTO Globalisation and Nepal eds. A.P.Shrestha, NEFAS, Kathmandu.

Harriot, V.J. 2003. Can Corals Be Harvested Sustainably? Ambio Vol.32, No.32

Mastny, L. 2001. Traveling Light: New Path for International Tourism, eds. J.A. Peterson, World Watch Paper 159, World Watch Institute.

McCalla, A. F. 1999. "World Agricultural Directions: What Do They Mean For Food Security?" (Paper presented at Cornell University, sponsored by CIIFAD, March 30)

Non-Wood News. 2003. Biopiracy in Africa, non- Wood News No. 10, FAO.

Pistorius, R. and J. van Wijk (1999) The Exploitation of Plant Genetic Information. Political Strategies in

Rifkin, J. 1998. The Biotech Century. Harnessing the Gene and Remaking the World (New York: Putnam).

Stevenson, M. 1998. Mexicans Are Increasingly Cut Off From Their Own Caribbean Coast. Chico (California) Enterprise- Record, December 13:1B

Thacker, V.P. 2003. Globalization, Free Trade, The Debt Crisis And Sustainable Development: A Comparative Study Of The North South Divide, in Exploring The Dynamics Of Global Change, eds. Viraj p. Thacker, Kathamndu.

TWN 1992. http://www.twnside.org.sg/order1.htm

Valliantos, M and A.Durbin. 1998. License To Loot: The MAI And How To Stop It. Friends of Earth.

Watkins, K. (1996) "Free trade and farm fallacies. From the Uruguay Round to the World 